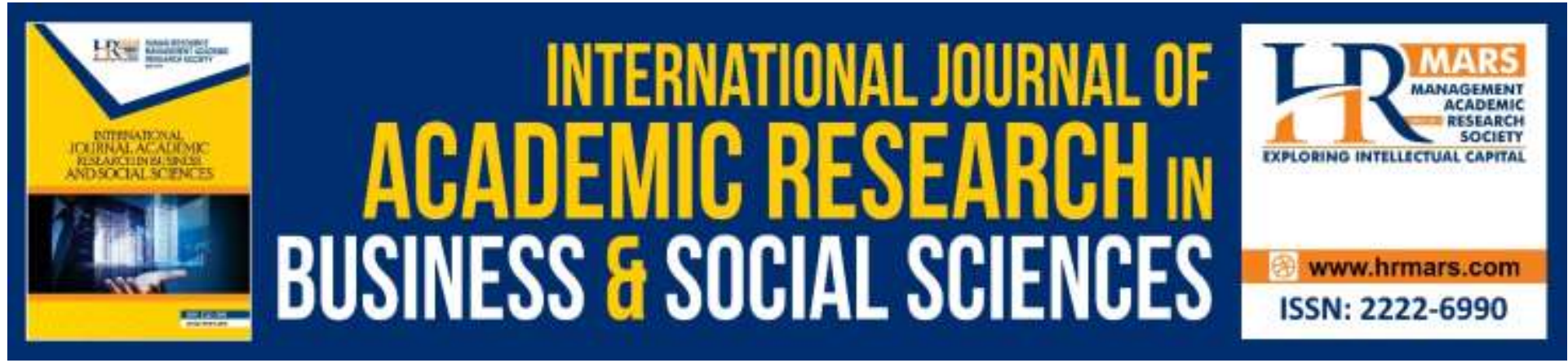

\title{
Tertiary Education Saving Patterns among Malaysian Parents
}

Fatimah-Salwa Abd. Hadi, Mohd Yahya Mohd Hussin, Fidlizan Muhammad, Azila Abdul Razak, Nurhanie Mahjom, Mohamad Azahari Ahmad

To Link this Article: http://dx.doi.org/10.6007/IJARBSS/v9-i9/6411

DOI: $10.6007 /$ IJARBSS/v9-i9/6411

Received: 15 July 2019, Revised: 10 August 2019, Accepted: 30 August 2019

Published Online: 15 September 2019

In-Text Citation: (Hadi et al., 2019)

To Cite this Article: Hadi, F.-S. A., Hussin, M. Y. M., Muhammad, F., Razak, A. A., Mahjom, N., \& Ahmad, M. A. (2019). Tertiary Education Saving Patterns among Malaysian Parents. International Journal of Academic Research in Business and Social Sciencesrnational, 9(9), 1166-1175.

\section{Copyright: (C) 2019 The Author(s)}

Published by Human Resource Management Academic Research Society (www.hrmars.com)

This article is published under the Creative Commons Attribution (CC BY 4.0) license. Anyone may reproduce, distribute, translate and create derivative works of this article (for both commercial and non-commercial purposes), subject to full attribution to the original publication and authors. The full terms of this license may be seen at: http://creativecommons.org/licences/by/4.0/legalcode

\section{Vol. 9, No. 9, 2019, Pg. 1166 - 1175}

Full Terms \& Conditions of access and use can be found at http://hrmars.com/index.php/pages/detail/publication-ethics 


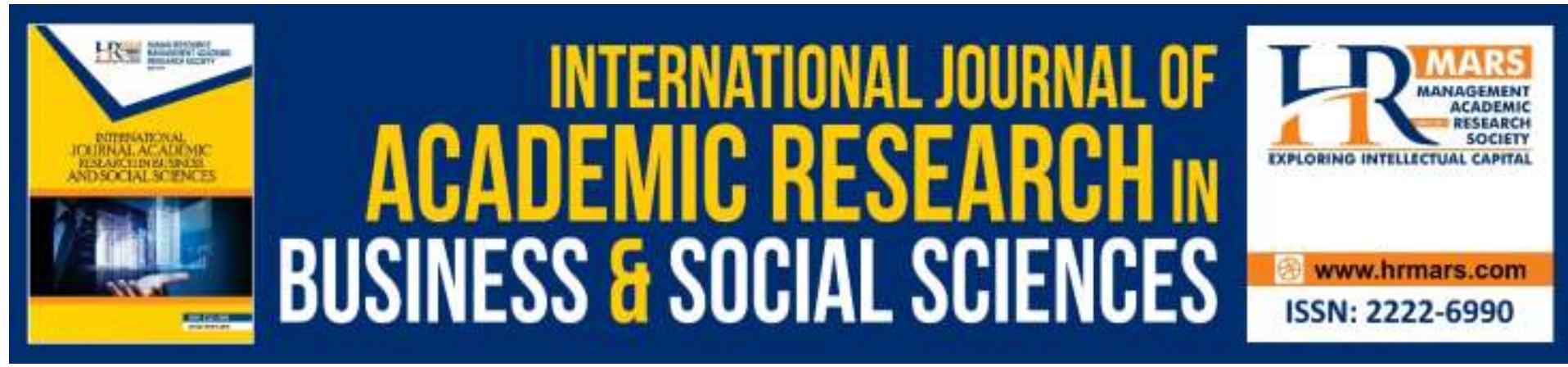

\title{
Tertiary Education Saving Patterns among Malaysian Parents
}

\author{
Fatimah-Salwa Abd. Hadi ${ }^{1}$, Mohd Yahya Mohd Hussin ${ }^{1}$, \\ Fidlizan Muhammad' ${ }^{1}$, Azila Abdul Razak ${ }^{1}$, Nurhanie Mahjom¹, \\ Mohamad Azahari Ahmad ${ }^{2}$ \\ ${ }^{1}$ Faculty of Management and Economics, Universiti Pendidikan Sultan Idris, 35900 Tanjung \\ Malim, Perak, Malaysia. \\ ${ }^{2}$ Shariah Compliance Unit, National Co-operative Movement of Malaysia Wisma Ungku \\ A.Aziz, Jalan SS6/1, 47301 Kelana Jaya, Petaling Jaya, Selangor, Malaysia \\ Email: fatimahsalwa@fpe.upsi.edu.my
}

\begin{abstract}
While tertiary education provides many benefits to the individual, the community and the nation, we cannot deny that the cost is high and continues to rise each year. The younger generation have to take up loans to finance their study costs and then they have to pay back the loans after completing their studies. As such, the funds from the parents can be seen as an alternative which could help in realizing the tertiary education goal. The question is, do the parents realize and know the importance of tertiary education savings? Have they saved for their children's education? How much do they save per month? Are the savings enough for their children's university education? What is the savings medium utilized to make savings? Therefore, this paper focuses on two main objectives. The first objective is to identify the patterns of children's tertiary education savings among parents in Malaysia and the second objective is to determine the medium of saving used by parents to save their money. The findings indicated that all the respondents knew and realized the importance of tertiary education savings for their children or those under their care. The majority of parents in the low income and high-income groups did not make any savings while those in the medium income group did save with a mean amount of RM755 per month. Additionally, all respondents who had saved for tertiary education agreed that their funds would not be enough to cover all the expenses. Some savings mediums had been utilized for the tertiary education fund such as banks, Tabung Haji and Amanah Saham Nasional Berhad (ASNB) and others. To encourage the saving habit, all parties including parents, the government, banks and others should play their part so that the children's tertiary education process would be a smooth, fuss-free journey.
\end{abstract}

Keywords: Expenses, Cost, Tertiary Education, Savings, Malaysia 


\section{Introduction}

In general, education is defined as a purposive, conscious or unconscious, psychological, sociological, scientific and philosophical process, which brings about the development of the individual to the fullest extent. It could also enable the achievement of the maximum development of society in such a way that one could enjoy maximum happiness and prosperity. In fact, education not only brings benefits to the individual, but also to other people, society and country (Kumar \& Sajjad Ahmad, 2007).

In the context of Malaysia, the education structure can be divided into two, namely pretertiary and tertiary education level. The former level starts from pre-school up to secondary school while the latter includes certificate, diploma, undergraduate, as well as postgraduate studies. Since education is considered as one of crucial elements for sustainable development, 16 percent of Malaysia's annual federal budget was spent on education in 2014 and this kept on increasing from time to time (Ministry of Education, 2017). One other hand, private higher education institutions also play important roles in providing the access to higher education at a higher cost (Welch, 2009). All these efforts are in line with the aim of Malaysian Ministry of Education (MOE) to increase the access and enrolment of tertiary education up to 53 percent by the year 2025 as stated in Malaysian Education Development Pelan 2015-2025.

Even though the access to tertiary education is getting bigger especially in Malaysia, the expenses like registration fees and cost of living keep increasing tremendously. Based on the report by Malaysia's Premier Education Resource Guide Online 2017, the total cost of living for a student on average at RM1,800 (US\$450) per month or RM21,600 (US\$5,400) per year. Basically, the cost of living includes accommodation, food/housekeeping, clothing and laundry, public transport, mobile phone bills, utilities, books, reading materials, stationary, medical and personal expenses. To ensure that the children are able to continue their tertiary education in a comfortable manner, some parents have started to save a certain amount of money as soon as possible. The parents hope that their savings could be sufficient to finance the study later on. Findings revealed by HSBC Bank showed that 57 percent of 411 Malaysian parents took up loans to fund their children's tertiary education even though they have a certain amount of saving. On average, parents in the country spent up to RM38,000 a year on their children's tertiary education (Mustafa, 2018).

Although tertiary education is important to produce an educated generation who can bring the sustainable development to the country, the expenses related to it are high and keep increasing over time. Thus, saving significantly plays an important role at least to cover some portion out of total expenses of the study at the tertiary level. Hence, do parents know and are they aware of the importance of saving for the children's tertiary education? Have the parents saved any money for their children's tertiary education? If they do so, what is the amount they saved? Is the amount of savings sufficient for the children's tertiary education? What are the mediums used to save for the children's tertiary education? Therefore, this paper focuses on two main objectives. The first is to identify the patterns of children's tertiary education savings among parents in Malaysia and the second is to determine the medium of saving used by parents to save their money. 


\section{Literature Review}

Many studies have been conducted on parent's saving on children tertiary education. However, most of them focused more on the factors affecting the saving pattern or behaviour. For example, Glick, Sahn, \& Walker (2016) and Deng, Huang, Jin, \& Sherraden (2014) concluded that income has become one of the most significant factors which influenced the parents' saving pattern while Hortz, Wiemers, Rasmussen, \& Koegel (2018) and Huang (2013) agreed on wealth or asset. On the other hand, Ogundari \& Abdulai (2014) found that educated parent also contribute to the existing of the savings since they knew and realized the important of saving for children education. However, Winter (2014) and Montalto, Phillips, McDaniel, \& Baker (2019) found that awareness was one of the more important factors. Besides that, Akaguri (2014) stressed that institutions played an important role to attract parents to save their money for the children's education. Moreover, Manly Wells, \& Bettencourt (2017) found out that the expectation of the parents on their children became one of the important factors. In addition, Dondero \& Humphries (2016) concluded that the environment or people in the society also contributed to the parents' saving pattern.

Elliot, Song, \& Nam (2013) proved that savings play an important role prior the enrollment of tertiary education. The children who were categorized into low and moderate income groups (below $\$ 50,000 ; n=512$ ) and high income group ( $\$ 50,000$ or above; $n=345$ ) were chosen to be the respondents of the study. By using propensity score weighted data from the Panel Study of Income Dynamics and its supplements, the study concluded that the children under the category of low and moderate income were more likely to enrol in and graduate from college when they had a small amount of savings. In addition, this group of children who had savings of \$1 to \$499 prior to their college age were over three times more likely to enrol in college and four times more likely to graduate as compared to the child with no savings account. These findings were basically in line with the study done by Friedline (2012); Ahmed, Majid, Zin, Phulpoto, \& Umrani, (2016) who concluded that parents' savings for their child were significant in low and high income households. 333 children from low and moderate income groups $(\$ 50,000)$ and 411 from high income group $(\geq \$ 50,000)$ were selected as respondents of the study. The study pointed out that the children from the ages of 12 to 15 years old who had some savings felt difficult to consistently save since they had short and long term expenses.

Elliott, Lewis, Grinstein-Weiss, \& Nam (2014) confirmed that parental support helped in reducing college debt. If there was no financial support from the parents, normally students would take a certain amount of debt to finance their tertiary education. This situation could be a burden for them after completing study. All data were collected from 2992 students and analysed by using Propensity Score Analyses and Multilevel Modelling. The results showed that the parental college savings can be part of a strategy to help in reducing college debt. In fact, the postsecondary education costs in the United States today are rising with an increasing shift from societal responsibility to individual burden, thereby driving greater student borrowing. Related to this matter, a study had been conducted in Malaysia by Zainal, Kamaruddin, \& Saiful Nathan (2009). A total of 371 parents of students from various universities and colleges were selected as the respondents. Based on the result, the study concluded that parental savings were insufficient to cover all costs in higher education. 


\section{Methodology}

This quantitative study involved 526 respondents who were chosen randomly. The respondents were parents or guardians of children who were studying in public educational institutions in Malaysia. A questionnaire was utilized to get the required information. The questionnaire was adapted from Elliott \& Friedline (2013); Galdeano, Ahmed, Fati, Rehan, \& Ahmed, (2019) and adopted according to the suitability and the study objectives constructed. The data was later analyzed descriptively.

\section{Findings}

The fourth part is divided into 2 sections. The first section will discuss the respondents' information while the second section will focus on the respondents' tertiary saving patterns.

\section{Profile of Respondents}

The table below shows the information about the respondents' who had taken part in the study. All the respondents involved were parents or guardians of students who were studying in any degree programme in public universities. 45.06 percent of the respondents are males while the remaining 54.96 percent are females. In terms of education level, almost 50 percent of them were degree holders, 24.52 percent had a diploma and less than 20 percent of them had a Sijil Pelajaran Malaysia (SPM) and Penilaian Menengah Rendah (PMR) education. Additionally, almost 50 percent of them were between the ages of 51 to 55 years old and only a small percentage were between 41 to 45 years old. 
Table 1: Information about Study Respondents

\begin{tabular}{|c|c|c|c|}
\hline Respondent Profile & Description & $\begin{array}{c}\text { Frequency } \\
(n=526)\end{array}$ & Percentage (\%) \\
\hline \multirow[t]{2}{*}{ Gender } & Male & 237 & 45.06 \\
\hline & Female & 289 & 54.94 \\
\hline \multirow{5}{*}{$\begin{array}{l}\text { Highest education } \\
\text { level }\end{array}$} & PMR & 17 & 3.23 \\
\hline & SPM & 69 & 13.12 \\
\hline & Diploma & 129 & 24.52 \\
\hline & Bachelor's degree & 249 & 47.34 \\
\hline & Master's degree & 62 & 11.79 \\
\hline \multirow[t]{5}{*}{ Age } & $41-45$ years & 3 & 0.60 \\
\hline & $46-50$ years & 119 & 22.62 \\
\hline & $51-55$ years & 258 & 49.05 \\
\hline & $56-60$ years & 54 & 10.27 \\
\hline & 61 and above & 92 & 17.46 \\
\hline \multirow[t]{3}{*}{ Job sector } & Government & 296 & 56.27 \\
\hline & Private & 111 & 21.10 \\
\hline & Self-employed & 119 & 22.63 \\
\hline \multirow{7}{*}{$\begin{array}{l}\text { Salary amount } \\
\text { (monthly) }\end{array}$} & $\mathrm{RM} 3,001-\mathrm{RM} 4,000$ & 104 & 19.77 \\
\hline & RM4,001 - RM5,000 & 39 & 7.41 \\
\hline & RM5,001 - RM6,000 & 47 & 8.94 \\
\hline & RM6,001 - RM7,000 & 69 & 13.11 \\
\hline & RM7,001 - RM8,000 & 115 & 21.86 \\
\hline & RM8,001 - RM9,000 & 96 & 18.25 \\
\hline & $\geq \mathrm{RM} 9,001$ & 56 & 10.66 \\
\hline \multirow{5}{*}{$\begin{array}{l}\text { Number of persons } \\
\text { in the household }\end{array}$} & 3 & 21 & 3.99 \\
\hline & 4 & 115 & 21.86 \\
\hline & $\begin{array}{l}5 \\
6\end{array}$ & 245 & 46.58 \\
\hline & $\begin{array}{l}6 \\
>7\end{array}$ & 139 & 26.43 \\
\hline & $\geq 7$ & 6 & 1.14 \\
\hline
\end{tabular}

Based on the occupations, 56.27 percent worked in the government sector, 21.10 percent worked in the private sector and the rest were self-employed. The respondents could be categorised into 3 groups: the low-income group (RM4,000 and below), the medium income group (RM4,001 to RM8,000) and the high-income group (RM8,001 and above). 19.77 percent of the respondents were categorised as low-income earners, 51.32 percent as medium income earners and 28.91 percent were high income earners. Additionally, almost 50 percent of the respondents had 5 people in their household while a small percentage (1.14 percent) had at least 7 people in their household. 


\section{Tertiary Education Savings}

To simplify the analysis, the respondents were divided into 3 groups of low-income, medium income and high income. The low-income respondents had a household income of RM4,000 and below. The medium income respondents had a household income of RM4,001 to $\mathrm{RM} 8,000$. As for the high-income group, these earners had an income of RM8,001 and above. The information about the tertiary education savings for the respondents' children could be seen in the table below.

Table 2: Information about Respondents' Tertiary Education Savings

\begin{tabular}{|c|c|c|c|}
\hline & $\begin{array}{c}\text { Low income } \\
\text { (RM4,000 and below) }\end{array}$ & $\begin{array}{c}\text { Medium income } \\
\text { (RM4,001 to RM8,000) }\end{array}$ & $\begin{array}{c}\text { High income } \\
\text { (RM8,001 and above) }\end{array}$ \\
\hline $\begin{array}{c}\text { Saved for } \\
\text { tertiary } \\
\text { education }\end{array}$ & $2(1.92)$ & $259(95.93)$ & $3(1.97)$ \\
\hline $\begin{array}{c}\text { Did not } \\
\text { save for } \\
\text { tertiary } \\
\text { education }\end{array}$ & $102(98.08)$ & $11(4.07)$ & $149(98.03)$ \\
\hline Total & 104 & 270 & 152 \\
\hline
\end{tabular}

Note: ( ) percentage value

The findings revealed that only 1.92 percent of the low-income respondents saved for their children's tertiary education. The remaining 98 percent did not make any contribution for their children's university education. Almost 96 percent of the medium income respondents saved for their children's tertiary education while a small 4.07 percent did not. As for the highincome group, 9.03 percent did not save for their children's education while less than 2 percent of them did make some contribution.

Additionally, the mean value for the monthly contribution for medium income respondents who saved for the tertiary education was RM755. The minimum and maximum monthly amounts were RM150 and RM1500 respectively. There were various mediums utilised by the parents for tertiary education savings. This would include savings in the bank, Tabung Haji and Amanah Saham Nasional (ASNB). Some parents and guardians had also saved in the form of gold savings or property investment. Additionally, all of the respondents (whether they saved for tertiary education or otherwise) knew that tertiary education costs were getting more and more expensive compared to primary and secondary education. However, all the respondents who had saved for their children's tertiary education agreed that what they accumulated would not be enough for their latter's expenses in the university. These findings were in line with the study by Zainal et al. (2009).

Based on these findings, we can conclude that the majority of low-income respondents did not make any tertiary saving for their children. This could be due to the lack of funds to be saved. With the remaining leftover funds from the monthly salary, other requirements needed to be prioritised such as food, clothing, housing and medical needs. The big number 
of children may also make it difficult for parents and guardians to save for tertiary education. This is different to the high-income respondents; the majority of them did not make any tertiary savings for their children. However, if their children managed to get a place in a tertiary institution, they would usually have enough money to cover all the costs involved.

The majority of respondents from the medium income group had made some savings for their children's tertiary education. They seemed to be aware of the increase in education costs for their children and they did have some remaining funds for this purpose. They were also aware that early savings could guarantee that their children or those under their care would be able to acquire tertiary education quite comfortably.

\section{Conclusion and Recommendation}

In line with rising education costs especially at the tertiary level, the function and role of savings are extremely important and undeniable. As such, parents and guardians of children need to save money for the latter's tertiary education as early as possible. This will not only help in developing a future generation which is highly educated but also enable the children to have a comfortable life when they are studying at the tertiary level. With enough funds, the children would not have to depend on the government to get financial aid ; in fact, they do not have to take loans to finance the education costs.

As such, everyone should work together to ensure that their children or those under their care are able to enrol in tertiary education without much fuss, even though the costs would be expected to rise in the future. Besides offering scholarships, the government would have to ensure that studying costs at the tertiary level are always relevant and acceptable. Industry players like banks and related agencies would have to be creative to offer savings schemes which are affordable and payable by all income groups including those who are in the lower income group. Extensive announcements should be made to provide full and accurate information to the public about the need to save for tertiary education.

\section{Acknowledgment}

This paper is based on the research project entitled Analisis Gelagat Simpanan Wang Penjawat Awam Terhadap Perbelanjaan Pendidikan Tertiari Tanggungan. The authors would like to extend their gratitude to the Research Management and Innovation Centre (RMIC), Universiti Pendidikan Sultan Idris, Perak, Malaysia for the University Research Grant [Code 2017-0253-107-01 (Geran Penyelidikan Khas Universiti Berteraskan Pendidikan 2017)] that helped fund the research.

\section{References}

Ahmed, U., Majid, A. H., Zin, M. L., Phulpoto, W., \& Umrani, W. A. (2016). Role and impact of reward and accountability on training transfer. Business and Economics Journal, 7(1). http://dx.doi.org/10.4172/2151-6219.1000195

Akaguri, L. (2013). Fee-free public or low-fee private basic education in rural Ghana: How does the cost influence the choice of the poor? Compare: A Journal of Comparative and International Education, 44(2), 140-161. Retrieved from https://doi.org/10.1080/03057925.2013.796816 
Deng, S., Huang, J., Jin, M., \& Sherraden, M. (2014). Household assets, school enrollment, and parental aspirations for children's education in rural China: Does gender matter? International Journal of Social Welfare, 23, 185-194. https://doi.org/10.1111/ijsw.12034

Dondero, M., \& Humphries, M. (2016). Planning for the American dream: The college savings behavior of Asian and Latino foreign-born parents in the United States. Population Research and Policy Review, 35(6), 791-823. Retrieved from https ://doi.org/10.1007/s1111 3-016-9409-x.

Elliot, W., Song, H-a., \& Nam, I. (2013). Small-Dollar Children's Savings Accounts and Children's College Outcomes By Income Level. Children and Youth Services Review, 35 (3), 560571. Retrieved from

Elliott, W., \& Friedline, T. (2013). "You pay your share, we'll pay our share": The college cost burden and the role of race, income, and college assets. Economics of Education Review, 33, 134-153. Retrieved from

Elliott, W., Lewis, M., Grinstein-Weiss, M., \& Nam, I. (2014). Student Loan Debt: Can Parental College Savings Help? Federal Reserve Bank of St. Louis Review, 96(4), 331357.

Friedline, T. (2012). Predicting children's savings: The Role of Parents' Savings for Transferring Financial Advantage and Opportunities for Financial Inclusion. Children and Youth Services Review, 34(1), 144-154. Retrieved from

Galdeano, D., Ahmed, U., Fati, M., Rehan, R., \& Ahmed, A. (2019). Financial performance and corporate social responsibility in the banking sector of Bahrain: Can engagement moderate? Management Science Letters, 9(10), 1529-1542.

Glick, P. J., Sahn, D. E., \& Walker, T. F. (2016). Household shocks and education investments in Madagascar. Oxford Bulletin of Economics and Statistics, 78(6), 792-813. https://doi.org/10.1111/obes.12129

Huang, J. (2013). Intergenerational transmission of educational attainment: The role of Malaysia? New Straits Times Online. Retrieved from

Kumar, S., \& Ahmad, S. (2007). Meaning, aims and process of education. Retrieved May 29, 2018 from http://sol.du.ac.in/Courses/UG/StudyMaterial/16/Part1/ED/English/SM1.pdf. Malaysia? New Straits Times Online. Retrieved from

Manly, C. A., Wells, R. S., \& Bettencourt, G. M. (2017). Financial planning for college: Parental preparation and capital conversion. Journal of Family and Economic Issues, 38(3), 421438. Retrieved from https://doi.org/10.1007/s1083 4-016-9517-0.

Ministry of Education Malaysia. (2017). 4 Executive summary PPPM 2015 2025. Retrieved March 1, 2017 from https://www.moe.gov.my/menumedia/mediacetak/penerbitan/pppm-2015-2025-pt

Montalto, C. P., Phillips, E. L., McDaniel, A., \& Baker, A. R. (2019). College Student Financial Wellness: Student Loans and Beyond. Journal of Family and Economic Issues, 40(1), 321. Retrieved from https://doi.org/10.1007/s10834-018-9593-4

Mustafa, Z. (2018, January 11). How much would it cost to pursue higher education in Ogundari, K., \& Abdulai, A. (2014). Determinants of household's education and healthcare spending in Nigeria: Evidence from survey data. African Development Review, 26(1), 1-14. Retrieved from 
Welch, A. R. (2009). Access and equity in Southeast Asian higher education: finance, state capacity, privatization, and transparency. Retrieved August 11, 2018 from http://graduate.kru.ac.th/eduad/eBook/ 881101/comparative2.pdf.

Winter, C. (2014). Accounting for the changing role of family income in determining college entry. The Scandinavian Journal of Economics, 116(4), 909-963. Retrieved from https://doi.org/10.1111/sjoe.12076

Zainal, N. R., Kamaruddin, R., \& Saiful Nathan, S. B. (2009). Socio-economic Status and Parental Savings for Higher Education among Malaysian Bumiputera Families. International Journal of Economics and Finance, 1(2), 170-173. 